\section{Bringing Top People Together}

TIIE Ciba Foundation seems anxious not to be misunderstood. This year for the first time its annual report is prefaced by a cosy introduction by the director, Dr. G. E. W. Wolstenholme, explaining the activities of the foundation. These include hospitality to visiting scientists (about 1,000 a year) in the foundation's headquarters in Portland Place, organizing meetings and publishing proceedings, awarding two annual lectureships, and supporting such things as the National Kidney Research Fund and the use of audiovisual aids in education. Of these, probably the most important is the organization of meetings at Portland Place, always private and limited in size to between 25 and 40 scientists from all over the world. During 1966, there were 120 such meetings, most in the biological and medical fields, although the foundation has also supplied a home for the Science of Science Foundation and takes an interest in problems of scientific communication and science polisy.

The most provocative aspect of the foundation's activities is its decision to limit the number of participants in its colloquia. This, the report says, is justified by the limited accommodation which the foundation has at its disposal, and by the assumption (backed up by research recently carried out at the foundation) that discussions tend in any case to be dominated by about five speakers. Undoubtedly, though, the need to limit the numbers gives rise to hard feelings and may sometimes impede the foundation's aim of promoting international co-operation. Large meetings may be unwieldy, but they are also able to foster a genuine sense of community-small closed meetings, however well chosen, may look like cliques.

The death of Lord Brain in December 1966 robbed the foundation of an outstanding supporter. He had been a trustee for ten years, and chairman of the executive council since 1959. The foundation has now announced that Professor F. G. Young, Master of Darwin College and Sir William Dunn professor of biochemistry in the University of Cambridge, is to take over both positions. Sir Eric Ashby, Lord Florey, Sir George Illoyd-Jacob and Lord Todd are the other trustees.

\section{Treading Carefully}

THe United States seems determined to prove that its support for a nuclear non-dissemination treaty is genuine. Last week the Atomic Encrgy Commission ordered four American companies who have been working on the gas centrifuge method of separating uranium isotopes to stop. This step was taken despite the declared opinion of the A.F.C. that the gas centrifuge method will probably not be competitive with gas diffusion methods for a decade. 'Thus, despite implying that the centrifuge process does not provide a means of producing fissionable isotopes in sufficient quantities to manufacture weapons, the A.E.C. has thought it worthwhile to call a halt.

This means that isotopes such as uranium-235 will continue to be scparated from natural uranium by the expensive gas diffusion method. The advantage of this method from the point of view of the treaty is that the plant needed is of enormous size, and can hardly go undetected. Gas centrifugation, in which the isotope mixture is contained in a hollow rotor turning at very high speed, has seemed to offer a means of separating isotopes while using a plant small enough to be concealed. The A.E.C. itself will continue to work on the gas centrifuge method, and will provide industry with the results of its work at some future date, if it determines that this would be in the national interest. All gas diffusion plants are run by the administration, although some companies have expressed interest in operating them commercially. In the present delicate diplomatic climate this is unlikely to come about, but the A.E.C. recently announced that it is co-operating with the Atomic Industrial Forum in its study of the feasibility and desirability of transferring one or more of the commission's gas diffusion plants to industry.

There are three gas diffusion plants in the United States, at Oak Ridge, 'T'cnnessee, Portsmouth, Ohio, and Paducah, Kentucky, which are operated for the A.E.C. by private contractors. These cost altogether $\$ 2 \cdot 3$ billion to build, and the A.E.C. says that they are now used primarily for the enrichment of uranium for civilian power reactors, although built of course for the weapons programme. Thanks to the co-operation of the A.E.C., the Atomic Industrial Forum, which represents mining, manufacturing, utilities and other sections of the nuclear power industry, will be able to see classified information about the plants. Until the study is complete in six to nine months, the A.E.C. will not entertain requests from other groups to undertake studies. Uranium enriching is now the only step in the fuel cycle of nuclear power reactors which is not performed by private industry in the United States, and the A.E.C. is bound to come under some pressure from diplomats both inside and outside America to keep it that way.

\section{Committee on Pollution}

THE National Academy of Sciences and the National Academy of Engineering in Washington have set up an Environmental Studies Board to co-ordinate the activities of both academies. The chairman will be Dr. Harold Gershinowitz, former chairman of the research council of Royal Dutch/Shell, originally a Harvard chemist. The principal interest of the Environmental Studies Board will be the abatement of pollution of all kinds, and a statement from the academies points out that a number of important studies are already under way, under the aegis of the National Research Council, of the actual effects of pesticide residues, food chemicals, medicated feeds for livestock and even the sonic boom.

\section{Breast Cancer Diagnosis}

THe results of a survey carried out by Bulbrook and Haywood on the island of Guernsey may help substantially with the early diagnosis of cancer of the breast. They have found (Lancet, i, 519; 1967) that, in a group of 4,850 women, those with abnormal amounts of 17-hydroxysteroids and aetiocholanolone in the urine were several times as likely to develop breast cancer. The most puzzling aspect of these results is that the abnormalities of excretion were by no means of a single type. Some of the women who afterwards developed cancer had high levels of aetiocholanolone and low or normal levels of 17-hydroxysteroids, while others in 